\title{
VIRTUAL BUSINESS PROJECTS IN THE CLASSROOM: ENHANCING INTERCULTURAL AND BUSINESS SKILLS OF STUDENTS
}

\author{
Jürgen Bleicher, Baden-Württemberg Cooperative State University Villingen- \\ Schwenningen, Germany, juergen.bleicher@dhbw-vs.de \\ Paul Forrester, Keele Management School, Keele University, UK, \\ p.forrester@keele.ac.uk
}

\section{Andrea Honal, Baden-Wuerttemberg Cooperative State University Mannheim, Germany, andrea.honal@dhbw-mannheim.de}

\author{
Emil Velinov, Skoda Auto University, Mlada Boleslav, Czech Republic, \\ emil.velinov@savs.cz
}

\section{Authors short-biography}

Jürgen Bleicher is Professor and Program Director for Management in Industry at the BadenWürttemberg Cooperative State University. Previously he gained experience in several positions in industrial enterprises, most latterly with ZF Friedrichshafen AG. He is strongly involved in theory to practice transfer and originated the BLIC Program. His research interests and work include Strategic Management, Business Models and International Management.

Andrea Honal is Professor of Marketing, HRM and Media and Head of Digital Learning Center at the Baden-Württemberg Cooperative State University in Mannheim. She completed a business administration degree and her doctorate in the field of "brand management" at the Justus-Liebig University. After successfully completing her dissertation, she worked for several years as a management consultant on a national and international level.

Dr. Paul Forrester is Senior Teaching Fellow in Enterprise and Management at Keele University in the UK. Following an industrial career in production management, he gained his doctorate from Aston Business School and worked as Director of MBA Programs at a number of UK universities. He is a specialist in cross-cultural management. He is the co-author of two Operations Management books and has over thirty years' record of publications in top academic journals and book chapters.

Dr. Emil Velinov is an Associate Professor at the Department of Management and Marketing at Skoda Auto University in the Czech Republic. Emil has previously worked for several multinational corporations including General Electric and Oracle. Currently he is acting as an Adjunct Professor at RISEBA University of Applied Science in Latvia, Wroclaw University of Economics in Poland and Plekhanov University of Economics in Moscow.

\section{Introduction}

Changed circumstances in the higher education field, new technological trends and global labor market requirements for graduates, have prompted universities to rethink and redesign their curricula to develop innovative teaching and learning concepts to prepare students for the global business world (Becker, 2017). The internationalization of business relationships offers companies, managers and employees tremendous opportunities for cross-cultural working, while exposing them to ambitious challenges at the same time. To manage organizations 
successfully in contemporary business, decision makers need to develop experience of international working at an early stage (Davis, 2015). Human resource managers need to attend to attracting, motivating, developing and retaining qualified employees and to providing appropriate working conditions and stimuli for such working (Schuchow and Gutman, 2014). Intercultural competence, professional skills and digital literacy are not unique characteristics, but a precondition for firms and individuals participate in the global labor market. Courses at universities to enable students to acquire cross-cultural competences in an international environment have become an important component for the managers of tomorrow and can increase the attractiveness of particular business schools in the eyes of potential applicants (Luethge et al, 2016). A fitting example and the basis for this chapter is the Blended Learning International Cooperation (BLIC) Program which originated and is being further developed at the Baden-Württemberg Cooperative State University in Germany (DHBW). Enabling students to experience realistic international business settings and so prepare them for future employment is an essential motivation of the BLIC Program.

A common idea together with pioneering spirit, motivation, and open-mindedness energizes BLIC members to develop and implement an innovative new learning approach. Partners strive for long term and enriching relationships, strengthen the BLIC network. The network welcomes new members from other universities. Within the program, students from different countries (Germany, UK, the Czech Republic and Iceland in 2018) worked in a virtual business setting in mixed teams for one semester. They were asked to develop innovative management strategies for entry of products and services into new markets. Important goals of the program were the preparation of students for the global workplace, their exposure to a technology-rich learning environment, and the acquisition of intercultural experiences at an early stage in their studies. A network of participating universities who share a common vision for developing cross-cultural competences and the willingness to cooperate have facilitated the implementation of innovative new learning approaches. Challenges, such as synchronizing work across different academic calendars and working together despite each partner's special curricula and course specifications, were developed as synergetic strengths in the BLIC program work as these reflected and simulated constraints frequently encountered when international businesses work together.

Lecturers from the four universities supported the students during the projects in the role of coaches. In tandem, an empirical research study was conducted to analyze the effects of the BLIC program, focusing not only on the reinforcement of students' intercultural and businessrelated competencies, but also to gauge the impact of new technologies and social media tools employed during the projects. The survey sample consisted of 111-student respondents from a total population of around 200 from the Baden-Württemberg Cooperative State University in Germany, Keele University in the UK and Skoda Auto University in the Czech Republic. The key findings confirmed that the program benefitted all participants in strengthening their technical, methodological, personal, social, and intercultural skills in virtual teamworking activities. Moreover, the students enjoyed the teamwork, even during demanding high-pace periods and the many challenging moments. The use of new technologies, social media and virtual learning portals such as Moodle were crucial instruments for a successful collaboration and prepared the students for future business life. 


\section{The Project Experience}

\subsection{The Basics}

Megatrends such as globalization and digitalization have considerable effects on the forms of education demanded within business schools. Regalado (2013) analyzes how online-course innovations disrupt education and explores the question of whether online-learning might be the most significant innovation influencing the education system in the last decade. The BLIC approach has been recognized as an advanced pedagogical concept. It is based on a case study scenario and is designed to foster competencies in the fields of international business, intercultural management, and technology rich-learning environments. Collaboration among participating universities builds upon the strengths and preferences of partners. Teams from different cultural backgrounds and nationalities, located spatially across the participating universities, contribute to the task with complementary know-how and skills, and act as consultants to the German student teams who act as their clients. The growing BLIC network and associated research activities have the potential to provide extensive and valuable insights to make technology-based teamwork and active learning more effective, efficient, exciting, and meaningful.

Key numbers and descriptors of the project/activity

The underlying pedagogical concept of BLIC was originally designed in 2013 the BLIC program was initiated at the Baden-Württemberg Cooperative State University in VillingenSchwenningen. Up to the end of 2018, eight universities from eight different countries, comprising 1,100 students from 25 different national backgrounds, have participated in the program. Longstanding partners are Keele University in Great Britain, Reykjavik University in Iceland, and ŠKODA Auto University in the Czech Republic. Teams from Iceland, the Czech Republic and the UK were allocated to one of the twenty German teams and worked closely together throughout the Fall 2018 semester, and particularly intensively during the first 6-7 weeks. The German student teams were the clients, and the consultant teams in the other countries provided specialist advice. The German teams at DHBW developed a business plan as part of their studies and identified a country for market entry for their business. They produced a presentation the other country teams in advance of the consultative exercise. Based on a modular concept, BLIC is an attractive learning experience for both Bachelor and Master students. In courses such as strategic management or marketing, team contributions might be based on PESTLE analyses, market research studies, or a cultural analysis. The collaboration phase amongst international teams spans over three to five weeks. An ideal seminar class cohort consists of five teams with three to five members each. All lecturers and students are enrolled on the DHBW Moodle platform but may use their locally provided technologies in addition.

\subsection{Learning objectives}

Learning objectives are vital to focus attention and resources effectively. All BLIC activities are aligned with the following three categories of objectives.

\subsubsection{Three subordinate categories for learning objectives}

Explicit objectives can be divided into the categories (a) "International Business" (b) "Intercultural Management” and (c) "Technology Rich Learning”. 
The first category (a) "International Business" comprises three elements. Students learn about business models and concepts in international business. A case study presents a typical problem in international business. Based on interactive lectures and team-based research efforts, participants identify and apply models and concepts that serve best to solve the specific problem. While working on their case, students are taught to analyse international value chains in regard to performance, sustainability, and growth. Team members contribute with their specific skills to solve problems, work creatively, and apply innovative approaches.

(b) Intercultural Management is the second category. Participants acquire intercultural communication skills by sensitizing them for factors driving the success of international communication. In addition to international communication skills, students will develop their cultural competence. A major benefit of a BLIC course is that students and faculty expand their global network, which lasts beyond the period of the course.

The third category is (c) "Technology Rich Learning". The underlying idea is that technology supports learning, yet does not drive the concept. The exercise thus stimulates effective reallife virtual teamworking in business organizations. To enrich the learning experience, students and faculty can freely make use of technologies such as Moodle, web conference software and email accounts provided by their university. Furthermore, student participants are encouraged to use additional mobile media such as Facebook or Skype, if this increases the motivation to collaborate, reflecting work and relationships in real business. However, work elements such as consultant reports, course materials or assignments have to be formally posted in the provided DHBW learning management system (based on Moodle) exclusively, again stimulating formal business requirements within firms or between partners.

\subsubsection{Learning objectives according to Bloom's Taxonomy}

Educational objectives that can be achieved through BLIC can be categorized according to Bloom's modified taxonomy and Bloom's digital taxonomy - from lower order thinking skills to higher order thinking skills. In the context of BLIC, Bloom's modified taxonomy is used to provide a visual representation of classified objectives and to align improvement efforts concerning the curriculum amongst involved lecturers (Bath, 2010). In addition to the widely recognized advantages of Bloom's modified taxonomy, the digital taxonomy is used to acknowledge the increasing relevance of technical possibilities (Blau, 2017). BLIC provides and benefits from a technology-rich learning environment. Applying a digital taxonomy is a desirable opportunity to gain first experiences in this context. 
Table 1: Application of Bloom's classification taxonomies of educational objectives to BLIC

\begin{tabular}{|c|c|c|}
\hline $\begin{array}{l}\text { Bloom's } \\
\text { modified } \\
\text { taxonomy }\end{array}$ & $\begin{array}{l}\text { Bloom's } \\
\text { digital } \\
\text { taxonomy }\end{array}$ & Functional Levels and Activities with digital tools \\
\hline remember & do & $\begin{array}{l}\text { Recognize and describe business concepts such as the } \\
\text { value chain, marketing mix, or break-even analysis. } \\
\text { Network with local and international team members } \\
\text { Search for instructions on Moodle }\end{array}$ \\
\hline understand & connect & $\begin{array}{l}\text { Explain, compare and interpret business concepts } \\
\text { Conduct online research using different databases for } \\
\text { concepts such as team dynamics, cultural diversity, } \\
\text { marketing plan }\end{array}$ \\
\hline apply & apply & $\begin{array}{l}\text { Use theoretical concepts to develop e.g. a marketing plan } \\
\text { or a reflective report. } \\
\text { Share, upload, and edit research findings, drafts, and final } \\
\text { versions of assignments }\end{array}$ \\
\hline analyse & conceptualize & $\begin{array}{l}\text { Compare different concepts } \\
\text { Outline and structure assignments such as reflective } \\
\text { report according to underlying concepts and priorities }\end{array}$ \\
\hline evaluate & evaluate & $\begin{array}{l}\text { Critique and assess input from different teams } \\
\text { Facilitate virtual team meetings } \\
\text { Blog comments and review input from different teams }\end{array}$ \\
\hline \multirow[t]{2}{*}{ create } & create & $\begin{array}{l}\text { Plan and produce bidding documents } \\
\text { Develop a slide show of a company profile with audio- } \\
\text { narration }\end{array}$ \\
\hline & share & $\begin{array}{l}\text { Collaborate on content online } \\
\text { Make findings, documents, and reports available to all } \\
\text { participants }\end{array}$ \\
\hline
\end{tabular}

Source: Authors

\subsection{Purpose and Description}

The driving idea behind collaborative online international learning is to provide students with the opportunity to become acquainted with the complexity and the potential pitfalls associated with international business. The complexity associated with blended learning and virtual teams, such as overcoming cultural differences and dealing with diverse communication styles (Köppel, 2009; O’Conner, Mortimer and Bond, 2011) can be challenging and demanding. The case study approach using client-consultant relationships challenges students to collaborate 
effectively and to overcome language and cultural hurdles as well as experiencing virtual teamwork and exploring and applying business concepts. Upon completion of this course, students are better prepared to identify factors driving the success of international business. Based on taught theory, state-of-the-art communication technology and the case simulation, students should be better equipped to cope with international business needs and recognize and compensate the impact of cultural aspects when they enter the workforce for real. The modular concept could be extended to allow collaboration beyond business students as there is no reason this approach should not be used in fields such as social work, engineering, or even interdisciplinary studies.

Courses follow a modular and flexible structure based on the competencies of the participating universities. Factors such as different academic calendars, special curricula, grading and evaluation standards, and any limitations on technical or financial support are barriers for collaboration. A modular structure enables participating institutions to contribute their particular competence and to build a semester teaching program based on complementary strengths.

The BLIC program includes traditional teaching and learning elements as well as virtual learning and collaboration sequences. Students are taught relevant business methods such as marketing planning, or financial budgeting to develop a business plan for international expansion.

The underlying case of BLIC goes back to a Foreign Trade and Investment Campaign of the German Ministry for Economic Affairs and Energy with the aim of boosting exports of products and services. The corresponding invitation for a tender encourages organizations whose products or services promote German culture and industry in a foreign country or region. Students from participating universities build management and consulting teams to develop a comprehensive business plan and to present their business idea to the grant awarding committee. Their business cases are assessed based on their potential to enhance international awareness and an understanding of what the industry has to offer. Generous financial grants are offered to companies, which submit business propositions convincing the jury (lecturers). In all runnings of the course so far the German students have acted as the management teams and so become the clients in the BLIC exercise.

At the same time, consulting teams from partner universities provide consulting services to the management teams. Their main responsibility is to provide expertise strengthening the business concept of the management teams. The management team is responsible to merge inputs in a way that their business idea will be translated into a convincing business plan that is worth winning the tender and associated financial support (see Exhibit 1). Students learn management and business concepts such as international value chain, PESTLE analysis, marketing management tools, and financial planning, as indicated in Exhibit 1. Mandatory assignments are country profiles and status reports. However, depending on the educational level (under/postgraduate) and competence of the consulting team, assignments can be adjusted. A team enrolled in a marketing course might provide a marketing plan, whereas a team enrolled in a finance course might serve better developing financial statements. 
Exhibit 1: Overview of BLIC Outputs and Collaboration (2018)

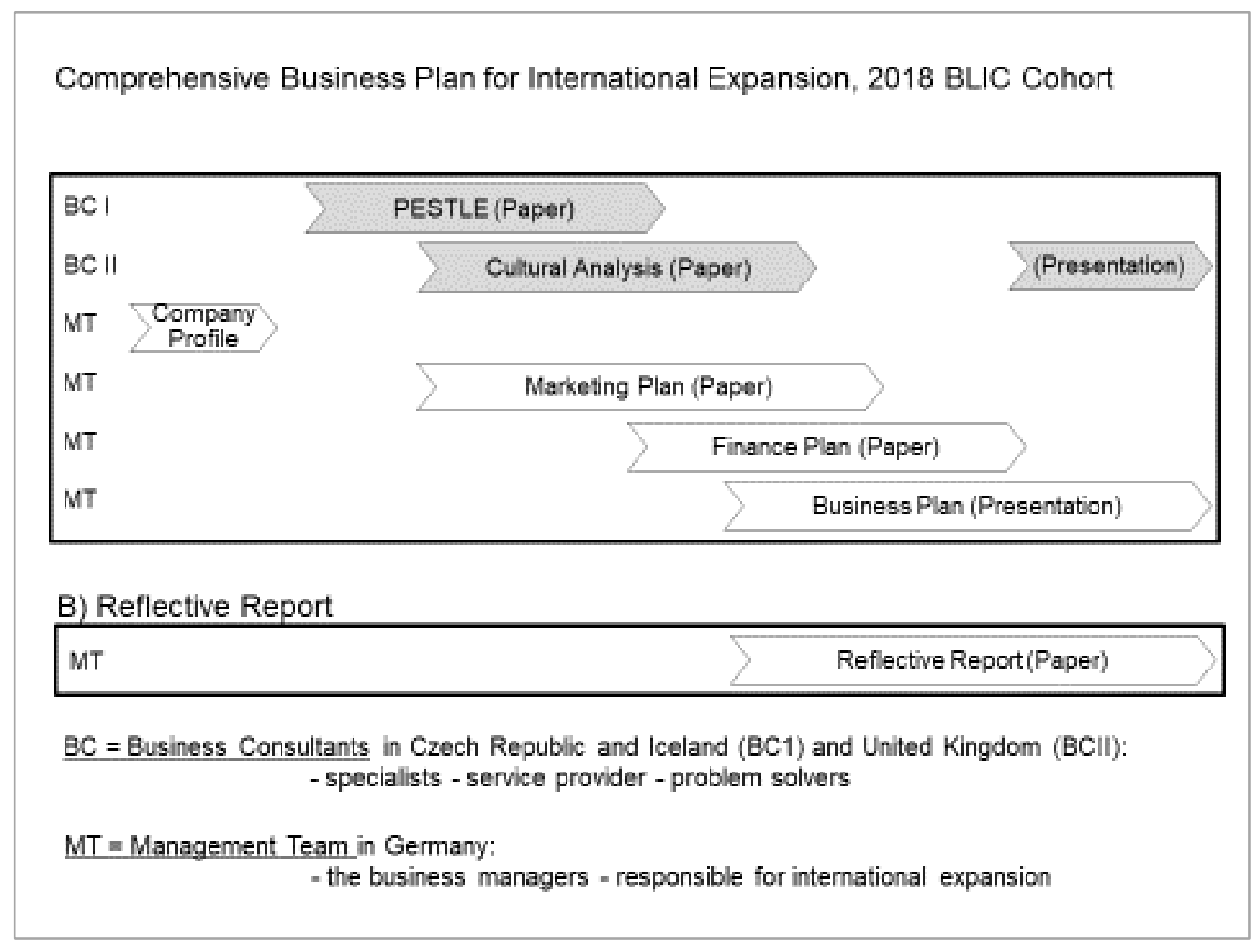

Source: Authors' elaboration

Because of the flexibility of the BLIC layout, clear role allocation, shared responsibilities and task delegation become critical success factors. All parties involved need to be aware of what they can expect and of what is expected from them. Clear briefings at all participating universities instruct students on the content and the grading criteria of assignments, as to make sure they understand the overall concept.

Acting on different levels, such as program, course, cohort, team, and local team level will enrich the learning experience of participants. Each team comprises at least two nationalities and two universities. A local learning team is a cooperative team of three to five students.

Students acquire relevant competencies in traditional classes. At the same time they use technologies such as WhatsApp, Facebook, Skype, video-conferencing tools, or Moodle virtual learning environment for collaborating in local and international teams. A technology-rich learning environment serves the underlying pedagogical concept. Besides the advantage of experiencing a realistic international business setting in the classroom, blended learning enables students and faculty to collaborate across borders and to overcome financial limitations.

Blended learning definitions in the literature emphasize the combination of face-to-face and virtual, technology-enabled communication as meaningful elements (Bonk and Graham, 2006; Le Rossignol, 2009). (Krause, 2007) best expresses the meaning of the team blended learning in the context of this paper. "Blended learning is realized in teaching and learning environments where there is an effective integration of different modes of delivery, models of teaching and styles of learning as a result of adopting a strategic and systematic approach to the use of technology combined with the best features of face to face interaction." (Krause, 
2007, p. 2). Blau et al. (2017) suggest intensifying the combined use of asynchronous and synchronous possibilities to provide learning opportunities in order to improve student learning. Students and faculty participating in the BLIC program can make use of any technology that best serve their purposes and that have a positive overall impact on their performance and motivation. Technology is not meant to drive the curriculum, but to serve learners and lecturers by setting an innovative and unique learning environment.

Ensuring that academic requirements are met and that a certain technological standard is available, using the DHBW learning management system is strongly suggested. Course materials, assignments and consultative reports are posted on Moodle. If students prefer other media to share ideas and to collaborate, they are welcome to do so as long as they post upload their assignments and consultants reports into folders on the DHBW learning management system by given deadlines.

\subsection{Experiential Learning Cycle}

The main purpose of the BLIC cooperation was to provide an active learning experience for students in the different countries. The consultant client exercise explained above mimics the real world of international cross-cultural project working. The business plan scenario is established by the German students, which sets the scene for the associated PESTLE and cultural analysis by students in the other countries.

Once the business plan scenario has laid the foundations, students in the different countries then develop concrete experience of working together using new technologies to accomplish a business outcome. An important part of the process following the exercise is the reflective observation of students in the different countries. The exercise can lead to distinctive forms of assessment. For example, in addition to more conventional forms of assessment and reflection, the UK partner uses the exercise as the basis for assessment whereby students produce posters based on their experiences and share these with staff and students alike at an end of semester poster event. This demonstrates how the experiential learning cycle occurs within the BLIC program.

BLIC therefore provides experiential cooperative learning involving several parties including students, teachers, study program directors and others. In the BLIC program, students from Germany, UK, Iceland and the Czech Republic are assigned to work together in consultantclient relationships for one semester in a virtual business setting in mixed teams and develop innovative management insights for new market-entry based business plans. The program aims to prepare students for the global workplace and collect intercultural and virtual teamwork experiences at an early stage during their studies. Lecturers from all participating universities support the students during their projects as coaches.

\subsection{Skills and competencies}

Project activities are designed to enhance student skills and competencies to prepare them for the international work environment in a globalized world.. A qualified labor force is a key success factor driving the future competitiveness of companies (Schültz, Strothmann, Schmitt and Laux, 2013). The BLIC program conveys how to establish and maintain long-term international business relationships. The program also aims at encouraging students to expand 
their international network and to increase participation in study abroad-programs. Exposing students to an international setting as early as possible allows them to discover potential future options, such as studying abroad, and serves as an icebreaker.

Students are prepared to identify factors driving the success of international business. BLIC is designed to enhance competencies such as recognizing, describing, explaining, comparing, interpreting, and applying business concepts through collaborative work. The case study requires participants to conduct research on appropriate business concepts. Students describe several theoretical models and apply them accordingly. Team efforts are focused on developing a comprehensive business plan. One element might be a finance plan calculating capital requirement for the intended expansion. Such a plan includes information on sales, price, customers, procurement, costs of current and fixed assets, marketing expenses, profitability, or investment appraisals. Another element of the business plan might be a value chain as a systematic evaluation of all firm activities. The value chain concept should highlight unique value creation processes as key sources of competitive advantage. However, requirements change according to the complementary strengths of participating partners.

Besides management aspects, learning teams are a vital part of the learning concept. They provide manifold opportunities to gain unique learning experiences based on collaboration skills. The freedom to work in international teams will prepare students for their future careers.

Students are expected to collaborate effectively and to respect human diversity. Learners should behave in a tolerant and professional manner. They collaborate with their peers to create a new and unique international business concept building upon the strengths of each learning team. Projects enable the development of individual skills, talents, and strengths of each team member and lead to innovative and successful international business relationships. Part of the assignments is a reflective report where participants summarize their experience of collaborating with local teams and international business partners. They identify challenges such as team dynamics, cultural differences, or communication practices, and provide recommendations for future projects.

With regard to the technology-rich learning environment, students are expected to find their instructions on Moodle. Furthermore, they learn how to effectively share and edit research findings, drafts, and final versions of assignments in the learning system. To complete the course successfully, participants conduct online research using different databases for concepts such as team dynamics, cultural diversity, or marketing plan. Regarding virtual collaboration, students develop a slide show presenting a company profile with audio-narration to become acquainted with the other teams and the business idea. Also, participants are enabled to facilitate virtual team meetings and to blog comments. Finally, team members understand how to review the input from different partners and therefore moving their collaborative work to the next level.

\subsection{Optimal Fit}

The international cooperation exercise is flexible enough to work in a number of different contexts. So far BLIC is principally being used for undergraduate and bachelor students, although master's students are now being incorporated into the process.

The most recent exercise in the Fall of 2018 involved total of nearly 200 students spread across the 4 countries, but could work equally well with smaller groups and, even with larger numbers, subject of course to adequate tutor resources. 
There is no reason why it should not be used on MBA courses as well, where post-experience students would add considerable value to the exercise. Participants can also be from different backgrounds and at least different levels of education. For example, it is a valuable experience for bachelor students to work with more experienced participants studying on part-time courses. This serves to replicate the real world of work further still.

\subsection{Challenges}

The BLIC exercise is deliberately designed to be challenging for participant students, and challenging it is. The first challenge for the tutors is ensuring the groups in the different countries engage the project work from the outset. The exercise demands considerable initiative and discipline on the part of students and some of them find this extremely demanding, having been used to more guided forms teaching and education.

Not only does the space between student teams and the use of virtual technologies present a challenge, but the practical of issue of deciding meeting times and insuring they understand each other's time zone presents many with a challenge. These initial problems and challenges are, in fact, positively embraced by the tutors on the modules, as they replicate the complexity and confusions in real business when working in these ways. Experiences and problems provide the basis for subsequent reflection. It is clearly the objective that, having learned from the mistakes that might have been made, participants would conduct themselves differently when faced with cross-cultural and virtual team working in the future workplace.

The exercise sets a diverse range of challenges when it comes to evaluation and marking. In addition to the normal challenges of group marking and peer assessment, many aspects of the work need to be considered in the grading of student work. Grading and assessment are tackled individually in each of the participating institutions, in line with the requirements for the modules and courses being taught. For example, in Germany students are required to produce and present their business plan, demonstrating that they have incorporated and learned from the experience with student colleagues at the other country institutions. The challenge is to identify relevant business issues they might face when developing and implementing their business plans. In the UK, where students are undertaking a comparative business cultures module, they are asked to evaluate and reflect upon their experience of cross-cultural and virtual teamwork by producing a poster. Posters are presented to staff and students at a special event at the end of the semester, and students are provided with a marking rubric setting out the marking criteria for their work. This exercise is all subject to peer review and assessment. The exercise enabled these student consultants to explore the implications of cultural issues they had learned about when implementing business concepts in different locations of the world. In Iceland and the Czech Republic, this involved students, who were assigned to deliver reports and separate PowerPoint presentations of approximately 20 slides on findings and results based on the PESTLE analyses. These two assignments addressed the syllabus learning outcomes, where group work engaged students and changed their mindset on the given subject.

\subsection{Evaluation of learning effectiveness}

The German students gained an awareness of client-consultant relationships and virtual teamworking processes, and how these might feed into and benefit their business plan and new market entry strategies. The reports from the consultant teams from Iceland, Czech Republic 
and the UK needed to be professionally presented and detailed enough to be of guidance, though concise in nature. This offered students the opportunity not just for cross-cultural and virtual teamwork experience, but also practice in working as a consultant (in some cases this was the students' first such experience) and in professional business report writing. The teams from different countries were expected to work closely with one another and had responsibility for making initial contact and managing the relationship, albeit moderated by tutors at each institution who monitored activities and intervened occasionally when this was seen as necessary to resolve any potential problems. Students were charged with organizing meetings, ensuring all team members attended, and deciding the best means for communication with their teams in other countries. They could use whatever form of communication worked best for them, but were encouraged to use the German partner's Moodle VLE system and Adobe Connect videoconferencing to facilitate their virtual meetings in addition to Skype, social media platforms, etc. Importantly students had to agree the channels of communication one another in order to avoid confusion and, as can be imagined, some team were better at doing this than others.

Regarding the learning effectiveness, BLIC had a positive impact on the students (Table 1). For the evaluation a seven-point Likert scale ( $1=$ "strongly disagree" to $7=$ "strongly agree") was utilized with different statements. All students assessed the program and their specific project as important, useful as well as interesting while also communicating their overall satisfaction with the participation. German students gave a lesser rating but all evaluations were above the average of 3,5. In conclusion, the BLIC program improved the learning performance of all students.

\begin{tabular}{|c|c|c|c|c|c|c|c|c|}
\hline $\begin{array}{c}\text { Evaluation of the } \\
\text { Learning } \\
\text { Effectiveness }\end{array}$ & \multicolumn{2}{|c|}{$\begin{array}{c}\text { Total Sample } \\
(\boldsymbol{N}=\mathbf{1 1 1})\end{array}$} & \multicolumn{2}{|c|}{$\begin{array}{c}\text { Germany } \\
(\text { N=59) }\end{array}$} & \multicolumn{2}{|c|}{$\begin{array}{c}\text { UK } \\
(\text { N=22) }\end{array}$} & \multicolumn{2}{|c|}{$\begin{array}{c}\text { Czech Republic } \\
\text { (N=30) }\end{array}$} \\
\hline & Mean & $\begin{array}{c}\text { Std. } \\
\text { Dev. }\end{array}$ & Mean & $\begin{array}{c}\text { Std. } \\
\text { Dev. }\end{array}$ & Mean & $\begin{array}{c}\text { Std. } \\
\text { Dev. }\end{array}$ & Mean & Std. Dev. \\
\hline $\begin{array}{c}\text { I believe that the } \\
\text { learning activity is } \\
\text { very important for } \\
\text { me. }\end{array}$ & 4,135 & 1,665 & 3,831 & 1,522 & 4,864 & 2,077 & 4,200 & 1,472 \\
\hline $\begin{array}{c}\text { Overall, the } \\
\text { learning activity is } \\
\text { excellent. }\end{array}$ & 4,081 & 1,652 & 3,593 & 1,391 & 5,364 & 1,787 & 4,100 & 1,561 \\
\hline $\begin{array}{c}\text { Overall, the content } \\
\text { of the learning } \\
\text { activity / project is } \\
\text { extremely } \\
\text { interesting. }\end{array}$ & 4,595 & 1,626 & 4,288 & 1,532 & 5,273 & 1,804 & 4,700 & 1,557 \\
\hline $\begin{array}{c}\text { In general, I find } \\
\text { the learning activity } \\
\text { is very useful. }\end{array}$ & 4,252 & 1,665 & 3,661 & 1,538 & 5,227 & 1,631 & 4,700 & 1,489 \\
\hline $\begin{array}{c}\text { I feel that I will } \\
\text { continue to profit } \\
\text { from that which I } \\
\text { have learnt after the } \\
\text { project has ended. }\end{array}$ & 4,279 & 1,743 & 3,831 & 1,499 & 5,636 & 1,529 & 4,167 & 1,877 \\
\hline
\end{tabular}

Table 1: Assessment of the Learning Effectiveness of BLIC 
In Table 2 the perceived competence improvement via BLIC participation is displayed. For the evaluation a Likert scale was used with different statements and a ranking from 1 = "strongly disagree" to $7=$ "strongly agree". The results confirm that the opportunity to work in an international team was rated positively, besides the fact that the participants could improve their English language and practical skills. The results also showed that the students had strengthened their technical, methodological, personal, social and intercultural skills within the project. In general, the evaluation results of the English and Czech students were on a higher level than the results of the German students. Nonetheless, all evaluations were above the average $(3,5)$.

\begin{tabular}{|c|c|c|c|c|c|c|c|c|}
\hline \multirow[t]{2}{*}{$\begin{array}{l}\text { Evaluation of the } \\
\text { BLIC Program }\end{array}$} & \multicolumn{2}{|c|}{$\begin{array}{c}\text { Total Sample } \\
(N=111)\end{array}$} & \multicolumn{2}{|c|}{$\begin{array}{c}\text { Germany } \\
(N=59)\end{array}$} & \multicolumn{2}{|c|}{$\begin{array}{c}U K \\
(N=22) \\
\end{array}$} & \multicolumn{2}{|c|}{$\begin{array}{c}\text { Czech Republic } \\
(N=30)\end{array}$} \\
\hline & Mean & Std. Dev. & Mean & $\begin{array}{l}\text { Std. } \\
\text { Dev. }\end{array}$ & Mean & Std. Dev. & Mean & Std. Dev. \\
\hline $\begin{array}{c}\text { I enjoy the work } \\
\text { in the BLIC } \\
\text { Project very } \\
\text { much. }\end{array}$ & 4,045 & 1,681 & 3,576 & 1,511 & 5,409 & 1,593 & 3,967 & 1,564 \\
\hline $\begin{array}{l}\text { I would } \\
\text { recommend } \\
\text { participating in } \\
\text { the BLIC } \\
\text { Program to other } \\
\text { students at my } \\
\text { university. }\end{array}$ & 4,144 & 1,705 & 3,542 & 1,478 & 5,545 & 1,565 & 4,300 & 1,622 \\
\hline $\begin{array}{l}\text { This program } \\
\text { helps me } \\
\text { strengthen my } \\
\text { technical } \\
\text { competence. }\end{array}$ & 4,288 & 1,686 & 4,051 & 1,547 & 5,136 & 1,833 & 4,133 & 1,697 \\
\hline $\begin{array}{l}\text { This program } \\
\text { helps me } \\
\text { strengthen my } \\
\text { methodological } \\
\text { competence. }\end{array}$ & 4,171 & 1,640 & 3,763 & 1,331 & 5,091 & 1,797 & 4,300 & 1,822 \\
\hline $\begin{array}{l}\text { This program } \\
\text { helps me } \\
\text { strengthen my } \\
\text { personal } \\
\text { competence. }\end{array}$ & 4,586 & 1,626 & 4,305 & 1,643 & 5,636 & 1,329 & 4,367 & 1,520 \\
\hline $\begin{array}{l}\text { This program } \\
\text { helps me } \\
\text { strengthen my } \\
\text { social } \\
\text { competence. }\end{array}$ & 4,802 & 1,606 & 4,559 & 1,523 & 5,682 & 1,359 & 4,633 & 1,752 \\
\hline $\begin{array}{l}\text { This program } \\
\text { helps me } \\
\text { strengthen my } \\
\text { intercultural } \\
\text { competence. }\end{array}$ & 5,072 & 1,559 & 4,864 & 1,502 & 5,727 & 1,279 & 5,000 & 1,762 \\
\hline
\end{tabular}

Table 2: Perceived Competence Improvement through the BLIC Participation

Additionally, the students evaluated the lecturers supporting the teams. For the assessment of the professors, a Likert scale was used with different statements and a ranking from $1=$ 
"strongly disagree" to 7 = "strongly agree". The results are displayed in Table 3. In general, all students were satisfied with the provided support. They received clear instructions, had an interactive dialogue and on-going communication with the lecturers. In summary, the students evaluated the technical and communication tools as very helpful for the global teamwork. Conclusively, the BLIC program provides a role model for enhancing internationality in curricula and for bringing didactics into line with current digitalization trends and practices.

\begin{tabular}{|c|c|c|c|c|c|c|c|c|}
\hline \multirow[t]{2}{*}{$\begin{array}{c}\text { Evaluation of the } \\
\text { Professors }\end{array}$} & \multicolumn{2}{|c|}{$\begin{array}{c}\text { Total Sample } \\
(N=111)\end{array}$} & \multicolumn{2}{|c|}{$\begin{array}{c}\text { Germany } \\
(N=59)\end{array}$} & \multicolumn{2}{|c|}{$\begin{array}{c}U K \\
(N=22)\end{array}$} & \multicolumn{2}{|c|}{$\begin{array}{c}\text { Czech Republic } \\
(N=30)\end{array}$} \\
\hline & Mean & Std. Dev. & Mean & Std. Dev. & Mean & $\begin{array}{l}\text { Std. } \\
\text { Dev. }\end{array}$ & Mean & Std. Dev. \\
\hline $\begin{array}{l}\text { The lecturers give } \\
\text { clear instructions. }\end{array}$ & 4,523 & 1,823 & 3,932 & 1,680 & 5,955 & 1,290 & 4,633 & 1,866 \\
\hline $\begin{array}{c}\text { The lecturers } \\
\text { have good } \\
\text { moderation skills. }\end{array}$ & 5,234 & 1,420 & 4,797 & 1,460 & 6,091 & 0,921 & 5,467 & 1,332 \\
\hline $\begin{array}{l}\text { The lecturers give } \\
\text { regular overview } \\
\text { of the next steps. }\end{array}$ & 5,423 & 1,398 & 5,085 & 1,317 & 6,364 & 1,136 & 5,400 & 1,453 \\
\hline $\begin{array}{l}\text { The lecturers } \\
\text { interact with all } \\
\text { team members. }\end{array}$ & 5,649 & 1,570 & 5,407 & 1,588 & 6,273 & 1,162 & 5,667 & 1,709 \\
\hline $\begin{array}{c}\text { The lecturers are } \\
\text { open for new } \\
\text { ideas. }\end{array}$ & 5,306 & 1,500 & 4,780 & 1,390 & 5,864 & 1,521 & 5,933 & 1,337 \\
\hline $\begin{array}{l}\text { The lecturers } \\
\text { regularly reflect } \\
\text { on the progress of } \\
\text { the project }\end{array}$ & 5,793 & 1,308 & 5,559 & 1,249 & 6,364 & 1,177 & 5,833 & 1,416 \\
\hline $\begin{array}{l}\text { The lecturers } \\
\text { listen to the team } \\
\text { members' issues } \\
\text { and try to help. }\end{array}$ & 5,892 & 1,377 & 5,525 & 1,490 & 6,682 & 0,568 & 6,033 & 1,326 \\
\hline $\begin{array}{l}\text { The lecturers' } \\
\text { feedback of the } \\
\text { responses is on a } \\
\text { good level. }\end{array}$ & 5,586 & 1,268 & 5,203 & 1,243 & 6,182 & 0,958 & 5,900 & 1,296 \\
\hline
\end{tabular}

Table 3: Assessment of the Lecturers

\subsection{Transferability}

Whole purpose of the BLIC exercise is to ensure students experience in a simulated environment the type of dynamics and issues that occur in the real workplace in terms of virtual and cross-cultural team working. Businesses and other not-for-profit organizations operate daily using information and communication technologies and communication between members in multiply-located teams. Students develop a set of relevant and transferable skills for such work that are relevant to the contemporary workplace.

Additionally, as already implied above, the exercise can be replicated across different fields of business and even to other disciplines. Multiple-located student teams could work together on projects involving different contents, i.e. not just using a business plan as the basis. For 
example, this teaching method could be utilized to good effect for engineering projects, law projects, or education projects. In fact, the list is almost endless. The key point here is that student participants learn how to operate on projects, in teams, and replicating the modern world of work where international collaboration and team working is an absolute must.

The BLIC program's design, from its initiation through to the current model of delivery, is clearly aligned with the "ethos approach" to internationalization that Qiang (2003:251) defines as one that "emphasizes creating a culture or climate that values and supports international/intercultural perspectives and initiatives. This approach acknowledges that the international dimension is fundamental to the definition of a university or any other institutions of higher learning". The best practices from this program are transferrable and applicable across the business schools and universities thanks to their complex and robust structure, which involves in-demand hard and soft skills for bachelor and master students.

\subsection{Debriefing}

Current study results shed a positive light on global blended learning concepts such as BLIC and indicate room for further concept development and future research activities (Becker et al., 2017). The study confirmed that the main learning objectives of the BLIC program were achieved. The students were able to improve their skills in the fields "intercultural management", "IT-/media competences" and "doing international business". By creating an own business concept for a new product or services for a foreign market, students learned what it takes to apply theoretical concepts and models towards their specific project and how to aggregate all relevant data. By acting within a diverse team, learners could increase their language and intercultural skills. The usage of different technological tools and working virtually were two core elements to keep the motivation and engagement of the participants on a high level. Moreover, it can be confirmed that Bloom's learning taxonomies, modified as well as digital, were considered in the BLIC program.

The students had to recall concepts and models from their earlier studies, e.g. value chain, and retrieve such information, as well as understanding newly found concepts. They needed to apply business concepts and demonstrate their use in their analyses. Concluding, participants had to evaluate and rate their milestones and results, not only within their own groups but also with other groups. In order to include Bloom's last taxonomy, they had to create bidding documents, following-up their progress and results in audio- and visual formats. For example, at Skoda Auto University the participants experienced some miscommunication with regards to their online virtual meetings with their German counterparts, who were bachelor students. The Czech and the German students have different learning processes and objectives, as each university focuses on their own specialisms and requirements. In future, each instructor/teacher should focus on how to provide more explicit and specific instructions to the participants working on BLIC projects. Special attention is needed to ensure continuous teacher support to the students throughout BLIC program, as it is vital for them to be guided and encouraged to perform through the whole lifespan of their projects. Moreover, it is necessary for each institution to organize internal debriefs in the form of workshop or roundtable after the completion of BLIC projects, to enable participants to share and provide constructive suggestions on how BLIC could be developed further.

The program and the student work had several challenging aspects. The coordination of virtual student projects with international partners is very time challenging. It requires highly motivated students and teachers to conduct their projects successfully. Furthermore, appropriate 
technical equipment and infrastructure has to be present and systematic preparation and continuous support are crucial to make the project realistic. Moreover, a systematic support by external stakeholder groups, e.g. cooperative firms, is helpful to conduct such kind of projects. The study results may be limited due to the sample size of only 111 participants. Still, the sample was sufficient to gain deeper insights concerning the BLIC program and its impact. Current trends and the positive effects of this alternative concept were confirmed. An on-going evaluation of the BLIC program is essential for improving and developing the concept on longterm perspective. Due to current circumstances, the BLIC program always needs to offer flexibility with respect to its program management and structure. The collaborating project partners should be stable as well as reliable. Enriching the BLIC program with new partners is an essential step towards the future use of this novel approach. The BLIC program must be adapted to future requirements and needs of the different stakeholder groups.

\section{Contributions/Implications}

BLIC projects reflecting real world virtual teamworking the student will meet as they enter business employment, as well as a practical insight to the nature of client/consultant relationships. Competencies of students are developed in communication technology and 'atdistance' teamwork and business management. There is substantial evidence these competences develop among students at the end of the process, as evidenced by their own reflections. BLIC project work also increases the engagement of teams and individuals within them in terms of serious group work. The BLIC project exercise provides pressures and challenges for students simulating the world of work they will soon be immersed in.

\section{Theoretical /conceptual contributions}

This blended-learning multinational program sheds light on students' cooperation through online and offline activities as different forms of learning have been demonstrated. These activities relate to core elements in Bloom's Taxonomy, but at the same time the use of different technological tools and working virtually were essential to maintain the motivation and engagement of student participants on a high level. Bloom's learning taxonomy, modified to digital learning (Krathwohl, 2002), was used in the design of the BLIC program. Students had to apply theoretical concepts to analyze and conceptualize their own experiences. Participants researched and analyzed concepts and models, e.g. value chain and the use of cultural analysis frameworks, to transfer them into practice. They had to evaluate and rate their milestones and results, not only within their own groups but also with collaborating groups in the other countries. In order to comply with Bloom's final taxonomy, the students had to create bidding documents, following-up their progress and results in audio- and visual formats.

\section{Pedagogical contributions}

The BLIC program helped ascertain teachers' and students' readiness to implement modern and novel forms of teaching and learning by not only applying business theory, , but digitalization, cross-cultural and teamwork competencies as well. In particular, teachers and students from the UK, Iceland and the Czech Republic had to adjust their teaching and learning styles in order to 
conform their mutual satisfaction and benefits from this program. Moreover, international cooperation has contributed to improving soft skills of the teachers and students as all parties had to practice such competences throughout the their whole project: providing instructions to the students, coordinating student groups, troubleshooting with via the Internet or dealing with individual requests. The BLIC program also demonstrated the relevance of appropriate integration of new technologies and innovative ideas into the curriculum of Bachelor and Master students. Students should face the demands of digitalization early in their studies order to meet with the changing requirements of working life. For firms, programs, like BLIC, are very valuable. Due to societal change and increasing competition for talent, enterprises have to to ensure their employer brand is attractive for future employees, especially for the 'millennial' generation. Offering international career options, the possibility to work abroad or in mixed teams, are highly attractive for the 'digital native generation'. The BLIC program directly contributes to the needs of companies wishing to attract and further develop a competent workforce. Consequently, the BLIC program facilitates contemporary and highly effective learning and knowledge sharing amongst international students and enhances their employability. Another far-reaching benefit is the modular design of BLIC, which enables it to be purposefully disseminated to other educational fields and subject areas..

\section{References}

Bath, D., \& Bourke, J. (2010). Getting Started With Blended Learning. Griffith Institute for Higher Education. Retrieved November 10, 2014, from http://www.griffith.edu.au/_data/assets/pdf_file/0004/267178/Getting_started_with_blend ed_learning_guide.pdf

Becker A., S., Cummins, M., Davis, A., Freeman, A., Hall Giesinger, C. and Ananthanarayanan, V. (2017), "New Media Consortium Horizon Report - 2017 Higher Education Edition", Online: http://www.nmc.org/publication/nmc-horizon-report-2017higher-education-edition/

Blau, G., Blessley, M., Kunkle, M., Schirmer, M., \& Regan, L. (2017). Toward understanding business student professional development engagement. Journal of education for business 92(3), 145-152.

Bonk, C. J., Graham, C. R. (Eds.). (2006): Handbook of blended learning: Global perspectives, local design. San Francisco, CA: Pfeiffer Publishing.

Churches, A. (2008, July 2). Bloom's Digital Taxonomy. Retrieved April 18, 2018, from http://www.scribxd.com/doc/8000050/Blooms-Digital-Taxonomy-v212.

Davis, G. L. Jr. (2015). Global boardroom talent: The new "must have". The Corporate Board, $36(210)$. 17-21.

Dahlstrom, E., Brooks, D. C., Grajek, S. and Reeves, J. (2015). "ECAR Study of Undergraduate Students and Information Technology", 2015, Report from EDUCAUSE, Online: http://net.educause.edu/ir/library/pdf/ss15/ers1510ss.pdf

Garrison, D.R., Vaughn N.D. (2007). "Blended Learning in Higher Education": Framework, Principles and Guidelines", San Francisco: Jossey-Bass Wiley 
Köppel, P. (2009). Virtuelle Teams: Die Rolle der Führung. In: Christoph I. Barmeyer, Jürgen Bolten (Eds.), Interkulturelle Personal- und Organisationsentwicklung. Sternenfels: Wissenschaft \& Praxis.

Krathwohl, D. R. (2002). “A revision of Bloom's Taxonomy: An Overview”. Theory Into Practice, 41(4), pp. 212-218.

Krause, K., (2007). Griffith University Blended Learning strategy. Document number 2008/0016252.

Le Rossignol, K. (2009). Designing blended learning in higher education: The neomillenial learner and mediated immersion. The International Journal of the Humanities, 6(10), 53 60 .

Luethge, D. J., Raska, D., Greer, B. M., O’Connor. C. (2016). Crossing the Atlantic: Integrating cross-cultural experiences into undergraduate business courses using virtual communities technology. Journal of Education for Business, 91(4), 219-226.

O’Conner, C. Mortimer, D. and Bond, S. (2011). Course management systems and blended learning: An innovative learning approach. International Journal of Employment Studies, $19(2), 62-82$.

Qiang, Z. 2003. Internationalization of Higher Education: Towards a conceptual framework. Policy Futures in Education. 1 (2): 148-270.

Regalado, A. (2013). The most important education technology in 200 years. MIT Technology Review, 116(1), 61-62

Schuchow, K, and Gutmann, J. (2014). Personalentwicklung: Themen, Trends, Best Practices. Freiburg: Haufe Verlag.

Schültz, B., Strothmann, P., Schmitt, C.T. and Laux, L. (2013). Innovationsorientierte Personalentwicklung: Konzepte, Methoden und Fallbeispiele für die Praxis. Wiesbaden: Springer Gabler. 


\section{BLIC PROJECT REPORT from Master students at Skoda Auto University}

Greenility, Group D3 (Czech consultants) - Report

The first contact for the BLIC project was an e-mail on 18th September. We learned more about the project in the first week of the winter semester where doctor Velinov presented the BLIC project and gave us more information. When contacting our Czech group, we found out that one student does not communicate with us at all and therefore will not cooperate with us during this project.

The first online meeting with students from Germany unfortunately did not happen because foreign students did not have the time. During the week we contacted the German group and tried to arrange an online appointment unfortunately unsuccessfully. Meanwhile in our group we created PESTLE analysis and answers to special questions given by the German group. During the project work, we lost another team member due to him quitting university.

The next week we sent our project work to the German group with all the notes and, once again, we tried to agree to an online meeting in order to present all the information. Finally, we were able to arrange a meeting during the very last week of this project and discuss all the crucial points with the German group. The communication went well and AdobeWebconnect software was identified as user-friendly for both sides.

This project has brought both advantages and disadvantages. The advantage of this group work was the cooperation with students from foreign university. It was also interesting and sometimes challenging to work in a virtual environment without any personal contact. Also creating a PESTLE analysis was something new for us. Our group was familiar with the theoretical background of this analysis, but we have never compiled such a document for practical purposes during our studies. Because of that, we have gained a better understanding of how the analysis should be created and why is it so important for the company to understand all the factors that may affect a functioning in a foreign market.

On the other hand, this kind of a long-distance cooperation brings some drawbacks and challenges that we have experienced. In our case the written communication via Moodle system did not go that well, therefore we had to set up a WhatsApp group in order to communicate more effectively. The other disadvantage that we have identified was a lack of flexibility from the German group in terms of the video conference calls. We were supposed to do three video calls during the three weeks period. Unfortunately, we managed doing only one call but not because of availability issues from our side. Cooperation within our group of consultants went very well even though one member of our team was not involved in the project at all and the other one left the project during the second week. The group work itself went smoothly and without any major issues. We have divided all the tasks evenly and completed the work on time.

To sum it all up, it was a great experience to be a part of this international project and it surely gave us a very good overview on working in international environment. However, we think that there is still a room for improvement in terms of video conference calls and communication between universities. 